\title{
1 A potential solution to mitigate phosphorus release following clearfelling in peatland forest
}

catchments

4 Connie O’Driscoll ${ }^{1}$, Michael Rodgers ${ }^{1}$, Mark O’Connor ${ }^{1}$, Zaki-ul-Zaman Asam ${ }^{1}$, Elvira de Eyto ${ }^{2}$, Russell Poole ${ }^{2}$ and Liwen Xiao ${ }^{1 *}$

${ }^{1}$ Civil Engineering, National University of Ireland, Galway, Republic of Ireland

${ }^{2}$ Marine Institute, Newport, Co. Mayo, Republic of Ireland

8 *Corresponding author: Liwen Xiao; Email: liwen.xiao@nuigalway.ie; Tel: +353 91 494188;

$9 \quad$ Fax: +35391 494507

\section{ABSTRACT}

13 Since the 1950s, large areas of upland peat have been afforested in northern European countries.

14 Due to the poor phosphorus (P) adsorption capacity and low hydraulic permeability in blanket

15 peat soil and increased labile $\mathrm{P}$ sources, harvesting these blanket peat forests can significantly

16 increase $\mathrm{P}$ concentrations in the receiving aquatic systems. This paper briefly reviews the current

17 management practices on the control of $\mathrm{P}$ releases from forestry in Ireland and the UK, and

18 proposes a possible novel practice - grass seeding clearfelled areas immediately after harvesting,

19 which should reduce P release from blanket peat forest harvesting. The study was conducted in

20 the Burrishoole Catchment in the west of Ireland. A field trial was carried out to identify the

21 successful native grass species that could grow quickly in the blanket peat forest. The two

22 successful grass species - Holcus lanatus and Agrostis capillaris - were sown in three blanket

23 peat forest study plots with areas of $100 \mathrm{~m}^{2}, 360 \mathrm{~m}^{2}$ and $660 \mathrm{~m}^{2}$ immediately after harvesting.

24 Areas without grass seeding were used as controls. One year later, the P content in the above

25 ground vegetation biomass of the three study plots were $2.83 \mathrm{~kg} \mathrm{P} \mathrm{ha}^{-1}, 0.65 \mathrm{~kg} \mathrm{P} \mathrm{ha}^{-1}$ and 3.07

$26 \mathrm{~kg} \mathrm{P} \mathrm{ha}^{-1}$, respectively, which were significantly higher than the value of $0.02 \mathrm{~kg} \mathrm{P} \mathrm{ha}^{-1}$ in the

27 control areas. The water extractable phosphorus (WEP) in the three study plots were $8.44 \mathrm{mg}(\mathrm{kg}$

28 dry soil $)^{-1}, 9.83 \mathrm{mg}(\mathrm{kg} \text { dry soil })^{-1}$ and $6.04 \mathrm{mg}(\mathrm{kg} \text { dry soil })^{-1}$, respectively, which were lower

29 than the value of $25.72 \mathrm{mg}\left(\mathrm{kg}_{\mathrm{dry}} \text { soil }\right)^{-1}$ in the control sites. The results indicate that grass

30 seeding of the peatland immediately after harvesting can quickly immobilize significant amounts 
of $\mathrm{P}$ and warrants additional research as a new Best Management Practice following harvesting

32 in the blanket peatland forest to mitigate $\mathrm{P}$ release.

34 Key words: P release. Blanket peat. Forest harvesting. Grass seeding. Holcus lanatus. Agrostis capillaris

\section{INTRODUCTION}

Forest harvesting disrupts the phosphorus $(\mathrm{P})$ cycle of forest ecosystems and increases labile $\mathrm{P}$ sources in the soil, which could result in an increase of $\mathrm{P}$ release. $\mathrm{P}$ at concentrations of $30 \mu \mathrm{g} \mathrm{l}^{-1}$ could trigger eutrophication in freshwaters (Boesch et al. 2001). Eutrophication has been identified as the most important water quality problem in the UK and Ireland (EPA 2004), particularly for the generally oligotrophic salmonid rivers and lakes, which are very sensitive to pollution. Therefore, $\mathrm{P}$ release after harvesting is of significant concern in upland blanket peat forest catchments, such as the Burrishoole catchment in the west of Ireland, which contains salmonids and has a great risk of $\mathrm{P}$ release due to the poor phosphorus (P) adsorption capacity and low hydraulic permeability of the peat soil. Since the 1950s, large areas of upland peat have been afforested in northern European countries. Previous studies have documented the effects of peatland forest harvesting on P release. In Southern Finland, Nieminen (2003) found an increase in phosphorus release at three out of four peatland forest study sites after harvesting. In the west of Ireland, Cummins and Farrell (2003) investigated the biogeochemical impacts of clearfelling with regard to phosphorus on blanket peatland streams and noted that in three drains the molybdate-reactive phosphorus (MRP) increased from $9 \mu \mathrm{g} \mathrm{l}^{-1}, 13 \mu \mathrm{g} \mathrm{l}^{-1}$ and $93 \mu \mathrm{g} \mathrm{l^{-1 }}$ before

54 harvesting to $265 \mu \mathrm{g} \mathrm{l}^{-1}, 3530 \mu \mathrm{g} \mathrm{l}^{-1}$, and $4164 \mu \mathrm{g} \mathrm{l^{-1 }}$, respectively, one year after harvesting.

55 Recently, Rodgers et al. (2010) carried out a study in the Burrishoole catchment in the west of

56 Ireland and found that the daily mean total reactive phosphorus (TRP) concentration in a study 57 stream increased from about $6 \mu \mathrm{g} \mathrm{l^{-1 }}$ pre-harvesting to $429 \mu \mathrm{g} \mathrm{l^{-1 }}$ one year after harvesting, even 58 though best management practices were strictly implemented. Four years after clearfelling, the $\mathrm{P}$ 59 concentrations returned to the pre-harvesting concentrations. In the first three years after

60 harvesting, up to $5.15 \mathrm{~kg} \mathrm{ha}^{-1}$ of TRP was released from the harvested catchment to the receiving 61 water; in the second year alone, $2.3 \mathrm{~kg} \mathrm{ha}^{-1}$ of TRP was released. These results indicated that the 
62 water quality of lakes, rivers and streams in the blanket peat forest catchments could be

63 threatened by possible increases of $\mathrm{P}$ in runoff water arising from forest harvesting.

\section{Current mitigation methods}

67 Buffer zones, which can filter the runoff before it reaches the receiving water, are widely used by 68 forestry practitioners in the management of freshwater aquatic systems. They can protect aquatic 69 systems by controlling runoff: (i) mechanically, by increasing deposition through the slowing 70 down of flow; (ii) chemically, through reactions between incoming nutrients and soil matrices and residual elements; and (iii) biologically, through plant and microbial nutrient processes. Buffer zones have been recognized as an efficient method to remove suspended solids and attached P and could remove $14 \%$ to $91.8 \%$ of total phosphorus (TP) (Table 1). However, its effectiveness on dissolved reactive phosphorus (DRP) removal has been controversial. In their study, Vought et al. (1994) found that buffer strips were very efficient in DRP removal, with the removal efficiency of 95\%. In contrast, Uusi-Kämppä (2005) found that their naturally vegetated buffer zone became a P release source, responsible for $70 \%$ of DRP release. Stutter et al. (2009) indicated that vegetated buffer zones increased soil $\mathrm{P}$ solubility and the potential amount $\mathrm{P}$ release. In Ireland and the UK, many of the earlier afforested upland blanket peat catchments were established without any riparian buffer areas, with trees planted to the stream edge (Ryder et al., 2010). Ryder et al. (2010) carried out a study on the creation of riparian buffer zones in three blanket peat forest in the west of Ireland and concluded that it was a technically challenging felling operation. In their study, Rodgers et al. (2010) found that in the Burrishoole catchment most of the $\mathrm{P}$ release after harvesting occurred in soluble form during storm events, raising concerns about the effectiveness of buffer zones in blanket peatland catchments.

In order to reduce nutrient sources, whole-tree harvesting (WTH) is recommended (Nisbet et al. 1997). In the UK, WTH is usually achieved by removing the whole tree (i.e. all parts of the tree above the ground) from the site in a single operation (Nisbet et al. 1997). In Ireland, in

90 experimental trails conducted by Coillte, an adapted WTH procedure was adopted where the

91 forest harvest residues are bundled and removed from the selected sitse after the conventional

92 harvesting of stem wood (personal communication, Dr. Philip O’Dea, Coillte Teoranta, 2010). 
93 Needles and branches have much higher nutrient concentrations than stem wood and whole-tree 94 harvesting may reduce nutrient sources by 2 to 3 times more than bole-only harvesting (Nisbet et 95 al. 1997). Rodgers et al. (2010) found higher water extractable $\mathrm{P}$ content in the areas below 96 windrow/brash material than the brash-free areas in the harvested upland peat forest catchment 97 and indicated that whole-tree harvesting could be used as a mean to decrease P release. Yanai 98 (1998) reported negligible P loss to streams over three years from harvesting using the whole99 tree harvesting method (all parts of tree above the ground) at the Hubbard Brook Experimental 100 forest in New Hampshire. However, whole tree harvesting can remove most of the nutrients as 101 well as base cations (Nisbet et al. 1997), which could have a negative impact on the next crop 102 rotation, especially in blanket peat catchments. Walmsley et al. (2009) found that removal of 103 forest residues can reduce second rotation productivity through nutrient shortage.

105 Phased felling is recommended in the UK (Forest Commission 1988) and Ireland (Forest Service 106 2000) to diminish the negative impact of harvesting on water quality. Harvesting appropriately 107 sized coupes in a catchment at any one time can minimise the nutrient concentrations in the main 108 rivers (Rodgers et al. 2010). In their study, Cummins and Farrell (2003) found higher P 109 concentrations in the smaller drains, which covered higher proportion of harvesting area. 110 Rodgers et al. (2010) carried out a study on the impact of harvesting on the downstream 111 receiving river. The study stream and the main river have the areas of about 25 ha and 200 ha, 112 respectively. They found that although the $\mathrm{P}$ concentrations in the study stream were up to about $113420 \mu \mathrm{g} \mathrm{TRP}^{-1}$, the average $\mathrm{P}$ concentrations in the receiving water of the main river were $7 \pm 5$ $114 \mu \mathrm{g}$ TRP $~^{-1}$ - about $10 \mathrm{~m}$ upstream of the confluence of the study stream with the main river 115 (USC), and $9 \pm 8 \mu \mathrm{g}_{\text {TRP }}^{-1}$ - about $30 \mathrm{~m}$ downstream of this confluence (DSC). In a storm 116 event, when the TRP in the study stream increased from about $3 \mu \mathrm{g}$ TRP $l^{-1}$ to $292 \mu \mathrm{g}$ TRP $1^{-1}$, 117 the TRP concentrations at the DSC in the main river increased from about $5 \mu \mathrm{g}$ TRP $~^{-1}$ to about $11811 \mu \mathrm{g}$ TRP $1^{-1}$, which was much lower than the critical value of $30 \mu \mathrm{g}$ TRP $\mathrm{l}^{-1}$. Phased felling is 119 being used widely in Ireland. However, this management strategy does not reduce the total P load 120 leaving the harvested catchment, which could be bound to the bed sediment of the receiving 121 waters. If the $\mathrm{P}$ concentration in the river bed or lake sediment increases above the saturation 122 point, it could be released and become available to phytoplankton (EPA 2004). 


\section{A possible novel practice - grass seeding}

126 The increase of $\mathrm{P}$ release is due to the disruption of the $\mathrm{P}$ cycle after harvesting, which reduces 127 the catchment's $\mathrm{P}$ conservation capacity. The conservation of nutrients is dependent on a 128 functional balance within the intra-system cycle of the ecosystem and critical to this balance is 129 the uptake of water and nutrients by plants. Previous studies have indicated that vegetation can 130 retain the available $\mathrm{P}$ in situ and reduce $\mathrm{P}$ release from forest activities. In Finland, Silvan et al. 131 (2004) demonstrated that plants are effective in retaining P in peatlands. In China and Australia 132 vetiver grass in buffer zones and wetlands has shown a huge potential for removing $\mathrm{P}$ from 133 wastewater and polluted water (Wagner et al. 2003). Loach (1968) found that Molinia caerulea 134 could uptake $3.4 \mathrm{~kg}$ TP/ha in the wet-heath soils. Sheaffer et al. (2008) reported a P uptake of 30 $135 \mathrm{~kg} / \mathrm{ha}$ by Phalaris arundinacea in their wastewater treatment sites. However, recovery of blanket 136 peat vegetation following forest harvesting usually takes several years. Connaghan (2007) found 137 that Juncus effusus could develop in riparian areas within three years of clearfelling, whereas 138 further away from the river where peat depth increased and soil fertility decreased vegetation 139 took six to ten years to recover.

141 It appears that natural re-vegetation arising from the seed bank is likely to be too slow to 142 significantly mitigate against the $\mathrm{P}$ from felling, which mainly occurs in the first three years after 143 harvesting (Rodgers et al. 2010; Cummins \& Farrell 2003). In order to minimise the release of 144 nutrients to receiving waters after harvesting, a rational approach is to maximise the ground 145 vegetative growth over the first year after harvesting. This can be achieved by seeding the 146 clearfelled area with fast-growing suitable native vegetation. Sowing herbaceous species to 147 reduce soil erosion has been widely used during the first year after forest fire (Ruby 1989). 148 However, no study has been done on the possibility of sowing grass immediately after harvesting 149 to mitigate nutrient release. In this study, we examined if seeding grasses immediately after 150 harvesting would have potential as a new forestry best management practice (BMP). It is 151 hypothesized that by sowing the appropriate grass species in the blanket peat forest area 152 immediately after harvesting, significant amounts of $\mathrm{P}$ will be quickly taken up and conserved in 153 situ, which will result in reduced $\mathrm{P}$ release. To test this hypothesis, a trial experiment was first 154 carried out to identify the successful germination grass species in the blanket peatland. The grass 
155 species were then sown in three harvested blanket peat forest plots. The biomass and P content of 156 the above ground vegetation were tested one year after grass seeding. In order to compare $\mathrm{P}$ up

157 take by vegetation in seeded versus natural re-vegetated areas, vegetation surveys were also 158 carried out in nine blanket peat forest sites which were harvested 1-5 years ago in the west of 159 Ireland.

\section{MATERIAL AND METHODS}

\section{Site description}

The study was carried out in nine sites in County Mayo in the west of Ireland (Figure 1; Table 2). A total of nine sites were surveyed for natural re-vegetation in the blanket peat area after harvesting. All the sites have similar soil type and hydrological conditions. They are covered with blanket peat and overlie mainly quartzite and schist bedrock receiving an average precipitation of over 2,000 $\mathrm{mm}$ per year. During the harvesting operation, boles were removed, and tree residues (i.e. needles, twigs and branches) were collected together to form the brash material mats and windrows. A second rotation of Pinus contorta was planted in all sites within 6 months after harvesting, except in the Glennamong and Teevaloughan. No fertilizer was applied in the replanting operation.

\section{Trial and plot-scale experiment}

Ten widespread native Irish grass species, which were considered to be suitable for the purpose 178 of this study, were chosen for the trial experiment. They included: (1) Agrostis capillaris, (2) Epilobium angustifolium, (3) Eriophorum vaginatum, (4) Festuca rubra, (5) Holcus lanatus, (6)

180 Juncus effusus, (7) Lolium perenne, (8) Molinia caerulea, (9) Phalaris arudinacea and (10)

181 Phragmites australis. Grass seeds were purchased from Emorsgate Seeds, Norfolk, UK.

183 Previous to the field trial test, a sample of seeds was tested for viability using a controlled 184 laboratory germination test (Rao et al. 2006). For each species, 25 seeds were placed in a petri185 dish on $42 \mathrm{~mm}$ diameter Whatman filter paper, with 8 replicates. $3 \mathrm{ml}$ of distilled water was 
added and the dishes were arranged in cultivation chambers with fluorescent tubes of white light and a light/ darkness timer, at $15-25^{\circ} \mathrm{C}$. Dishes were sampled daily during three weeks. A seed was considered germinated when the radicle emerged. Distilled water was added whenever moisture loss was detected.

In the field trial test, a total of thirty three plots with an area of $900 \mathrm{~cm}^{2}$ each were defined in the brash free area in Teevaloughan site (Site 7 in Figure 1 and Table 2). 300 seeds of each of the ten candidate species were scattered on three replicate plots (10 x 3 plots). Three replicate control plots were also included. The plots were surveyed weekly for four months. Percent seedling emergence was calculated as the number of visible seedlings divided by the total number of seeds scattered on each plot.

In the Glennamong site (Site 8 in Figure 1 and Table 2), an area of about 1 ha was clearfelled in August 2009 and three plots of $100 \mathrm{~m}^{2}$ (plot 1), $360 \mathrm{~m}^{2}$ (plot 2) and $660 \mathrm{~m}^{2}$ (plot 3) were identified for the grass seeding plot-scale study. Each plot received the same sowing treatment, which comprised of a 50:50 ratio of Holcus lanatus and Agrostis capillaris. The ground was undisturbed and the seed was distributed evenly by hand at an initial rate of $36 \mathrm{~kg} \mathrm{ha}^{-1}$ on top of the old forest residue layer in October 2009. December 2009 and January 2010 were exceptionally cold months and a layer of snow measuring $30 \mathrm{~cm}$ in depth was recorded above the seeded area. To eliminate the risk of seed establishment failure the plots were seeded again in February 2010 at the same rate of $36 \mathrm{~kg} \mathrm{ha}^{-1}$. The area which was not seeded was used as control.

To estimate the aboveground vegetation biomass in nine study sites, thirty two $0.25 \mathrm{~m} \times 0.25 \mathrm{~m}$ quadrats were randomly sampled (Moore and Chapman 1986) in each site in August 2010. All vegetation lying within the quadrat was harvested to within $1 \mathrm{~cm}$ and dried at $80{ }^{\circ} \mathrm{C}$ in the

213 laboratory on the day of collection for 48 hours. Samples were then weighed and the biomass 214 was calculated by using Equation 1. Total phosphorus (TP) content of the vegetation was 215 measured in accordance with Ryan et al. (2001). About $1 \mathrm{~g}$ of dry matter from each sample was weighed, ground and put into a furnace at a temperature of $550^{\circ} \mathrm{C}$ overnight, then $5 \mathrm{ml}$ of $2 \mathrm{~N}$ 
$217 \mathrm{HCl}$ was added to extract the $\mathrm{P}$ and subsequently diluted to $50 \mathrm{ml}$ with deionised water. $\mathrm{P}$ in the 218 solution was analyzed using a Konelab 20 Analyser (Konelab Ltd.).

$220 \quad B_{p}=\frac{W t}{S t} \times 10000$

Equation 1

221 Where $\mathrm{Bp}$ is the biomass production $(\mathrm{kg} / \mathrm{ha})$; Wt is the total dry weight of the samples $(\mathrm{kg})$ and 222 St is the total area $\left(\mathrm{m}^{2}\right)$.

\section{Soil water extractable phosphorus (WEP) measurement}

100-mm-deep soil cores consisting of the humic and upper peat layers were collected using a 30mm-diameter gouge auger in the Glennamong site. 4, 8 and 14 soil samples were taken from plot 1, 2 and 3, respectively. Soil samples were analyzed for gravimetric water content and water extractable $\mathrm{P}$ (WEP). The core samples were placed in bags, hand mixed until visually homogenized, and subsamples of approximately $0.5 \mathrm{~g}$ (dry weight) were removed and extracted in $30 \mathrm{ml}$ of deionised water, and measured for P using a Konelab 20 Analyser. The remaining core samples were dried to determine their gravimetric moisture contents (Macrae et al. 2005).

\section{Data analysis}

In order to investigate the effects of grass seeding on total above ground biomass production, grass phosphorus uptake and soil water extractable phosphorus, data collected in the sown and control plots were compared by using t-tests. All statistical analyses were conducted using the SPSS statistical package for windows.

\section{RESULTS}

\section{Biomass and $P$ content of natural re-vegetation in blanket peat forests after harvesting}

245 Figure 2 shows the biomass and $\mathrm{P}$ content of natural re-vegetation in 9 study sites. The biomass 246 of the above ground vegetation has a strong linear relationship with years after harvesting (Figure 
2a). Vegetation appears to begin recolonising about one and half years after harvesting. 5 years

248 later the above ground vegetation linearly increased to about $6000 \mathrm{~kg}$ biomass $\mathrm{ha}^{-1}$. P content in

249 the above ground vegetation also linearly increased and reached $3.5 \mathrm{~kg} \mathrm{TP} \mathrm{ha}^{-1}$ five years after 250 harvesting (Figure 2b).

\section{Successful germination grass species}

Figure 3 shows the germination rates of ten grass species examined in laboratory conditions. Most species germinated successfully within three weeks. Agrostis capillaris, Phalaris arudinacea, Phragmites australis and Holcus lanatus have the highest viable rates of $99 \%$, $68.5 \%, 64 \%$ and $60.5 \%$, respectively. Molinia caerulea has the lowest rate of only $2 \%$. Low Molinia caerulea germination rates of 3\% and 9\% were also reported by other researchers (Grime et al. 1981; Grime et al. 1988; Brys et al. 2005). In their study, Grime et al. (1981) believed that the low germination percentage could be due to the low temperature.

During the 16 week field trial study in Teevaloughan, no grass growth was observed in the control plots. In the study plots, 7 out of 10 grass species successfully germinated. At the end of the study, Holcus lanatus, Agrostis capillaris, Festuca rubra, Phragmites australis, Phalaris arudinacea, Lolium perenne and Epilobium angustifolium had the germination rates of $44 \%$, 41\%, 57\%, 8\%, 11\%, 18\% and 3\%, respectively (Figure 4). Holcus lanatus, Agrostis capillaris and Festuca rubra had the highest germination rates. However, Festuca rubra was observed to be discoloured towards the end of the study period, as was noted by O'Toole et al. (1964), which could be due to poor nutrients concentrations in the soil. Similar phenomena were also found in Phragmites australis and Lolium perenne, which died back after week 7 and week 9, respectively. Only 2 species -Holcus lanatus and Agrostis capillaris - germinated successfully in the forested peatland habitat, and continued to grow and thrive up to 13 weeks after seeding and are considered to be suitable for the purpose of this study.

\section{Impact of grass seeding on the biomass and $P$ content of above ground vegetation}


of Holcus lanatus and Agrostis capillaris increased the above ground vegetation biomass and $\mathrm{P}$ 279 content one year after grass seeding. While there was very little vegetation growth in the control 280 plots (22 kg biomass ha ${ }^{-1}$ with P content of $\left.0.02 \mathrm{~kg} \mathrm{TP} \mathrm{ha}^{-1}\right)$, vegetation biomass of $2753 \mathrm{~kg} \mathrm{ha}^{-1}$, $281723 \mathrm{~kg} \mathrm{ha}^{-1}$ and $2050 \mathrm{~kg} \mathrm{ha}^{-1}$ were observed in the three study plots, giving the TP content of 2.83 $282 \mathrm{~kg} \mathrm{ha}^{-1}, 0.65 \mathrm{~kg} \mathrm{ha}^{-1}$ and $3.07 \mathrm{~kg} \mathrm{ha}^{-1}$, respectively (Figure 5). The above ground biomass and $\mathrm{P}$ 283 content in the sown plots was significantly higher than in the control plots ( $t$ test, $p<0.01$ ). The 284 vegetation collected for testing was cut to $1 \mathrm{~cm}$ aboveground level so these estimates could in fact 285 be higher when taken below ground biomass production into account which has been estimated 286 at $30 \%$ of the total plant biomass (Scholes and Hall 1996). In the UK, Goodwin et al. (1998) 287 found that Holcus lanatus produced biomass of $3405 \mathrm{~kg} \mathrm{ha}^{-1}$ with P concentrations of $1.64 \mathrm{mg}$ 288 289

Impact of grass seeding on soil water extractable phosphorus

Figure 6 shows the water extractable phosphorus (WEP) concentrations in the sown plots and the control plots. The WEP in the three study plots were $9 \mathrm{mg} \mathrm{P}$ (kg dry soil $)^{-1}, 12 \mathrm{mg} \mathrm{P}$ (kg dry soil) 1 and $6 \mathrm{mg} \mathrm{P}(\mathrm{kg} \text { dry soil })^{-1}$, respectively, which was significantly lower than the value of $27 \mathrm{mg}$

\section{DISCUSSION}

In this study, Calluna vulgaris, Molinia caerulea and Juncus effusus are the main species presenting at the natural re-vegetation sites. Similar findings were reported by Connaghan (2007).

301 Recovery of blanket peat vegetation following forest harvesting usually takes several years 302 (Connaghan 2007). In this study, it took five years for the natural re-vegetation to have the above 303 ground biomass of $6000 \mathrm{~kg} \mathrm{ha}^{-1}$. In a study by Allison \& Ausden (2006) where plots were 304 established on pine plantation heathland, which was recently clearfelled, it took four years for an 305 increase in percentage frequency of Calluna vulgaris - a native heathland species - to appear. In the west of Ireland, Connaghan (2007) carried out grass surveys in 8 blanket peat sites and found that bare soil could still account for 35\% one year after harvesting. The slow vegetation recovery 
309 bank, (2) the burial of the seed bank by a thick layer of needle litter and (3) the slow germination

310 characteristics of the seeds typically found at these sites (Pywell et al. 2002).

312 In a study to improve the peatland for the purpose of agriculture, O'Toole et al. (1964)

313 highlighted the difficulties involved in attempting to identify successful species to seed peatland

314 in Ireland. Grennan and Mulqueen (1964) sowed seed mixtures of Italian ryegrass (Lolium

315 multiflorum L.), perennial ryegrass (Lolium perenne L.), cocksfoot (Dactylis glomerata), timothy

316 (Phleum pratense), late flowering red clover (Trifolium pratense) and white clover (Trifolium

317 repens $L_{\text {. }}$ ) in the blanket peatland and found that when there were no phosphorus additions, all

318 sown species died off after germination. In this study, only 2 grass species - Holcus lanatus and

319 Agrostis capillaris - were found to germinate successfully and continue to grow in the harvested

320 blanket peat forest areas. After 10 years of study, O'Toole et al. (1964) found that Holcus lanatus

321 was one of the most suitable species for seeding blanket peatland. In a study on the effects of

322 sowing native herbaceous species on the post-fire recovery in a heathland, Fernández-Abascal et

323 al. (2004) found that Festuca rubra appears before Agrostis capillaris and dies back earlier also.

324 They deemed Agrostis capillaris a more suitable species than Festuca rubra. In a study

325 investigating spatial and temporal patterns of growth and nutrient uptake of five co-existing 326 grasses, Veresoglou and Fitter (1984) found that Holcus lanatus displays a maximum nutrient 327 uptake when soil moisture content and extractable P were high. In contrast, they found Agrostis

328 capillaris had a tendency to uptake peak $\mathrm{P}$ when the soil was drier. The use of these two 329 herbaceous species in this study may complement one another through increasing uptake 330 duration.

332 Piirainen et al. (2007) found that as ground vegetation develops, P uptake and recycling can be 333 expected to diminish leaching over time. In this study, the relatively low WEP in the study plots 334 is likely to be a result of P up-take by the seeded grasses. Holcus lanatus and Agrostis capillaris 335 have been reported to have high P uptake capacity. Veresoglou and Fitter (1984) carried out a 336 study on nutrient uptake in five co-existing grasses and found that Holcus lanatus and Agrostis 337 capillaris could uptake $16.9 \mathrm{mg} \mathrm{TP}\left(\mathrm{m}^{2} . \mathrm{d}\right)^{-1}$ and $2.7 \mathrm{mg} \mathrm{TP}\left(\mathrm{m}^{2} . \mathrm{d}\right)^{-1}$, respectively. As WEP has 338 strong linear relationship with TP concentrations in the runoff (Schindler et al. 2009) and has 339 been proved to be a useful indicator of soluble P concentrations in peat soil runoff water (Daly 
340 and Styles 2005), it is expected that the reduction of WEP in the grass seeded plots could result 341 in reduction of $\mathrm{P}$ runoff release.

\section{FUTURE RESEARCH}

345 Future research on the potential of grass seeding as forestry BMP should measure stream 346 chemistry to assess the success of the practice at protection water quality. It is expected that the $\mathrm{P}$ 347 measured in the grass would render a corresponding reduction in the $\mathrm{P}$ exported by the stream 348 after harvesting. However this has not been addressed by this study.

Sowing grass immediately after harvesting may affect forest regeneration. The inter-specific interactions between seeded grasses and the replanted seedlings can be positive and negative, and require further studies (Goldberg 1990; Maestr et al. 2004; Niu and Wan 2008; Maestr et al. 2009). The seeded grasses store significant amount of $P$ released from the peat and the logging residues. When the canopy of the next forest crop gradually closes over, the vegetation decays and releases the nutrients for uptake by the growing trees, which will facilitate forest regeneration. In fact, these nutrients slowly released from grass could be critical for the reforestation in peatlands, because of the poor nutrients of the soil and the low fertilisation rate limited by forest Guidelines (Forest service 2000). In contrast, the sowing grasses may compete for nutrients and lights with replanted seedlings in the first few years after seeding ( $\mathrm{Li}$ et al. 2010). However, this negative impact can be diminished by choosing the right seeding rates and seeding distance from the seedlings. Future research could be carried out on an appropriate seeding rate, to ensure the nutrient release to the receiving water, the competition with the replanted seedlings and the costs can be minimized.

\section{CONCLUSION}

The results of this study indicate that (1) Holcus lanatus and Agrostis capillaris can be quickly established in blanket peat forest areas after harvesting and (2) sowing Holcus lanatus and Agrostis capillaris immediately after harvesting has the potential to immobilize the $\mathrm{P}$ that would 
371 vegetation biomass could be up to $3.07 \mathrm{~kg} \mathrm{P} \mathrm{ha}^{-1}$. Further research into the feasibility of grass 372 seeding as a potential new BMP is clearly warranted. Sowing the right grass species at 373 appropriate rates should diminish the deleterious effects of forest harvesting on surface water 374 quality and facilitate the forest regeneration.

375

\section{ACKNOWLEDGEMENTS}

378 The authors gratefully acknowledge the funding from the Department of Agricultural, Fisheries and Food in Ireland, COFORD, Ireland EPA, Coillte and the Marine Institute. They also acknowledge the assistance of Dr. Philip O'Dea, Mary O'Brian, Mary Dillane and Liz Ryder.

\section{REFERENCES}

Abu-Zreig, M., P.R. Ramesh, R.W. Hugh, N.L. Manon, and K.K. Narinder. (2003). Phosphorus removal in vegetated filter strips. Journal of Environmental Quality, 32, 613-619.

Allison, M., and M. Ausden. (2006). Effects of removing the litter and humic layers on heathland establishment following plantation removal. Biological Conservation, 127(2), 177-182.

Bhattarai, R., P. K. Kalita, and M. K. Patel. (2009). Nutrient transport through a Vegetative Filter Strip with subsurface drainage. Journal of Environmental Management, 90(5), 1868-1876. understanding, ecosystem restoration, and challenges for agriculture. Journal of Environmental Quality, 30, 303-320. 
401 Connaghan, J. (2007). Management options for forests on western peatlands: vegetation survey.

402 A report to Coillte Teoranta by John Connaghan (Unpublished).

403

404 Cummins, T., and E. P. Farrell. (2003). Biogeochemical impacts of clearfelling and reforestation

405 on blanket peatland streams I. phosphorus. Forest Ecology and Management, 180(1-3), 545-555.

Daly, K., and D. Styles. (2005). Eutrophication from agricultural sources - Phosphorus

Chemistry of Mineral and Peat Soils in Ireland. Technical report. Irish EPA, Published by the Environmental Protection Agency, Ireland.

Dillaha, T. A., R. B. Reneau, S. Mostaghimi, and D. Lee. (1989). Vegetative Filter Strips for Agricultural Nonpoint Source Pollution Control. Transactions of the ASAE, 32(2), 513-519.

EPA. (2004). Eutrophication of inland and estuarine waters. In the report: 'Ireland's Environment 2004'. Published by Ireland EPA, Dublin, Ireland

Fernández-Abascal, I., R. Tárrega, and E. Luis-Calabuig. (2004). Ten years of recovery after Management, 203(1-3), 147-156.

Forestry Commission. (1988). Forests and water guidelines. $1^{\text {st }}$ ed. London: HMSO. Revised ( $2^{\text {nd }}$

424 Forest Service. (2000). Forestry and Water Quality Guidelines. Department of the Marine and 425 Natural Resources, Dublin.

426 Goldberge DE (1990) Components of resource competition in plant communities. In Grace J.

427 Tilman D (eds). Perspectives in plant competition. New York: Academic press.

429 Goodwin, M. J., R. J. Parkinson, E. N. D. Williams, and J. R. B. Tallowin. (1998). Soil

430 phosphorus extractability and uptake in a Cirsio-Molinietum fen-meadow and an adjacent Holcus 
431 lanatus pasture on the culm measures, north Devon, UK. Agriculture, Ecosystems \&

432 Environment, 70(2-3), 169-179.

433

434 Grennan, E., and J. Mulqueen. (1964). Grass production on blanket peat I. Phosphorus

435 requirements. Irish Journal of Agricultural Research, 3, 37-49.

Grime, J.P., Hodgson, J.G. and Hunt, R. (1988). In: Comparative Plant Ecology: A Functional Approach to Common British Species, Unwin Hyman, London.

Grime, J.P., Mason G., Curtis A.V., Rodman J., Band S.R., Mowforth M.A.G., Neal A.M. and Shaw S. (1981). A comparative study of germination characteristics in a local flora. Journal of 442 Ecology, 69, 1017-1059.

Li Q., Liang Y., Tong B., Du X., Ma K. (2010). Compensatory effects between Pinus massoniana and broadleaved tree species. Journal of Plant Ecology, 3(3), 183-189

Loach, K. (1968). Seasonal Growth and Nutrient Uptake in a Molinietum. Journal of Ecology, $448 \quad 56(2), 433-444$.

Lowrance, R., R. Todd, J. Fail, O. Hendrickson, R. Leonard, and L Asmussen. (1984). Riparian forest as nutrient filters in agricultural watersheds. BioScience, 34, 374-377.

454 water and ground water phosphorus relationships in a partially harvested Boreal Plain aspen 455 catchment. Forest Ecology and Management, 206, 315-329.

457 Maestre FT., Callaway RM., Valladares F. (2009). Refining the stress-gradient hypothesis for 458 competition and facilitation in plant communities. Journal of Ecology, 97, 199-205. 
460 Maestre FT., Cortina J., Bautista S. (2004). Mechanisms underlying the interaction between

461 Pinus halepensis and the native late-successinal shrub Pistacia lentiscus in a semi-arid plantation.

462 Ecography, 27, 776-786

464 Magette, W. L., R.B. Brinsfield, R.E. Palmer, and J.D. Wood. (1989). Nutrient and sediment removal by vegetated filter strips. Transactions of the ASAE, 32(2), 663-667.

Mander, Ü., V. Kuusemets, K. Lohmus, and T. Mauring. (1997). Efficiency and dimensioning of riparian buffer zones in agricultural catchments. Ecological Engineering, 8(4), 299-324.

Mankin, K. R., D. M. Ngandu, C. J. Barden, S. L. Hutchinson, and W. A. Geyer. (2007). Grass-

Shrub Riparian Buffer Removal of Sediment, Phosphorus, and Nitrogen from Simulated Runoff.

Marttila, H. and B. Kløve. (2010). Managing runoff, water quality and erosion in peatland

Moore, P. D. and S.B. Chapman. (1986). Methods in Plant Ecology, Alden Press, Oxford.

Nieminen, M. (2003). Effects of clear-cutting and site preparation on water quality from a drained Scots pine mire in southern Finland. Boreal Environmental Research, 8, 53-59.

Nisbet, T., J. Dutch, and A. Moffat. (1997). Whole-Tree Harvesting. A Guide to Good Practice. Forestry Commission Practice Guide, Forestry Commission, Edinburgh, UK.

Niu SL. and Wang SQ (2008). Warming changes species competitive hierarchy in a temperate steppe of northern China. Journal of Plant Ecology, 1, 103-110 
491 Piirainen, S., L. Finér, H. Mannerkoski, and M. Starr. (2007). Carbon, nitrogen and phosphorus

492 leaching after site preparation at a boreal forest clear-cut area. Forest Ecology and Management, $493243(1), 10-18$

Pywell F.R, J. M. Bullock, David B. R,, LIZ Warman, K. J. Walker and P. Rothery (2003) Plant traits as predictors of performance in ecological restoration. Journal of Applied Ecology, 40(1),

Rao, N. K., J. Hanson, M. E. Dulloo, K. Ghosh, D. Nowel, and M. Larinde. (2006). Manual of seed handling in genebanks. Handbooks for Genebanks No. 8. Bioversity International, Rome, Italy.. Muller, and L. Xiao. (2010). Quantification of Erosion and Phosphorus Release from a Peat Soil Forest Catchment. Forest Ecology and Management. (In press).

Ruby, E.C. (1989). Rational for seeding grass on the Stanislaus Complex bum Proceedings of the 509 Symposium on Fire and Watershed Management. USDA General Technical Report PSW-109.

Ryan J., E. George, and R. Abdul. (2001). Soil and plant analysis laboratory manual. Second edition. Jointly published by the International Certer for Agricultural Research in the Dry Areas and the National Agricultural Research Center. Available from ICARDA, Aleppo, Syria.

Ryder, L., E. de Eyto, M. Gormally, M. Sheehy-Skeffington, M. Dillane and R. Poole. (2010). Riparian zone creation in established coniferous forests in Irish upland peat catchments: Physical, 517 press).

520 Assessing extractable soil phosphorus methods in estimating phosphorus concentrations in 521 surface run-off from Calcic Hapludolls. Soil use and management, 25(1), 11-20. 
523 Scholes, R.J. and D. O. Hall. (1996). The carbon budget of tropical savannas, woodlands and

524 grasslands. In: Breymeyer A.I., D. O. Hall, J. M. Melillo, and G. I. Agren. (Eds.) Global Change:

525 Effects on Coniferous Forests and Grasslands, SCOPE Volume 56. Wiley, Chichester.

527 Sheaffer C.C., Rosen C.J. and Gupta S.C. (2008). Reed Canarygrass Forage Yield and Nutrient

528 Uptake on a Year-round Wastewater Application Site. Journal of Agronomy and Crop Science,

$529194(6), 465-469$

531 Silvan N., H. Vasander, and J Laine. (2004). Vegetation is the main factor in nutrient retention in 532 a constructed wetland buffer. Plant soil, 25, 179-187.

534 Stutter, M. I., S. J. Langan, and D. G. Lumsdon. (2009). Vegetated buffer strips can lead to 535 increased release of phosphorus to waters: a biogeochemical assessment of the mechanisms, 536 Environmental Science and. Technology, 43, 1858-1863.

538 Syversen, N. and H. Borch. (2005). Retention of soil particle fractions and phosphorus in cold539 climate buffer zones. Ecological Engineering, 25(4), 382-394.

541 Uusi-Kämppä, J. (2005). Phosphorus purification in buffer zones in cold climates. Ecological 542 Engineering, 24(5), 491-502.

544 Veresoglou, D. S. and A. H. Fitter. (1984). Spatial and Temporal Patterns of Growth and

545 Nutrient Uptake of Five Co- Existing Grasses. Journal of Ecology, 72(1), 259-272.

551 Wagner, S., P. Truong, A. Vieritz, and C. Smeal. (2003). Response of Vetiver Grass to Extreme 552 Nitrogen and Phosphorus Supply. In: Proceedings of Third International Vetiver Conference, 553 Guangzhou, China. October 2003. 
555 Walmsley, J. D., D. L. Jones, B. Reynolds, M. H. Price, and J. R. Healey. (2009). Whole tree

556 harvesting can reduce second rotation forest productivity. Forest Ecology and Management, 557 257(3), 1104-1111.

558

559 Yanai, R. D. (1998). The effect of whole-tree harvest on phosphorus cycling in a northern

560 hardwood forest. Forest Ecology and Management, 104(1-3), 281-295.

562 Yates, C. R. and S. O. Prasher (2009). Phosphorus reduction from agricultural runoff in a pilot563 scale surface-flow constructed wetland. Ecological Engineering, 35(12), 1693-1701. 
Table list

Table 1 Performance of buffer zones on P removal

\begin{tabular}{|c|c|c|c|c|c|}
\hline Soil & $\begin{array}{l}\text { Total } \mathrm{P} \\
\text { removal }\end{array}$ & $\begin{array}{c}\text { Dissolved reactive } \\
\text { P removal }\end{array}$ & Vegetations & Width (m) & References \\
\hline Clay & $40 \%$ & 0 & Grass & 10 & Uusi-Kämppä (2005) \\
\hline Clay & $40 \%$ & $-70 \%$ & $\begin{array}{c}\text { Natural } \\
\text { vegetation }\end{array}$ & 10 & Uusi-Kämppä (2005) \\
\hline Silty loam & $14 \%$ & & Grass & 5 & Syversen and Borch (2005) \\
\hline Silty loam & $26 \%$ & & Grass & 10 & Syversen and Borch (2005) \\
\hline \multirow[t]{2}{*}{ Silty loam } & $40 \%$ & & Grass & 15 & Syversen and Borch(2005) \\
\hline & $70 \%$ & $75 \%$ & Grass & 113 & Bhattarai et al., (2009) \\
\hline $\begin{array}{l}\text { Silt, loam and } \\
\text { sand }\end{array}$ & $31 \%$ & & Grass & 2 & Abu-Zreig et al., (2003) \\
\hline \multirow{7}{*}{$\begin{array}{l}\text { Silt, loam and } \\
\text { sand }\end{array}$} & $89 \%$ & & Grass & 15 & Abu-Zreig et al., (2003) \\
\hline & $61 \%$ & & Grass & 4.6 & Dillaha et al., (1989) \\
\hline & $79 \%$ & & Grass & 9.1 & Dillaha et al., (1989) \\
\hline & $18 \%$ & & Grass & 4.6 & Magette et al., (1989) \\
\hline & $46 \%$ & & Grass & 9.1 & Magette et al., (1989) \\
\hline & & $66 \%$ & & 8 & Vought et al., (1994) \\
\hline & & $95 \%$ & & 16 & Vought et al., (1994) \\
\hline Peatland & $67 \%$ & & Forest & & Marttila and Kløve. (2010) \\
\hline Clay and sand & & $41 \%$ & Grass & 4.1 & Yates and Prasher (2009) \\
\hline \multirow[t]{3}{*}{ Silt loam } & $42.9 \%$ & & Grass & 8 & Mankin et al., (2007) \\
\hline & $67 \%$ & & & 20 & Mander et al., (1997) \\
\hline & $81 \%$ & & & 28 & Mander et al., (1997) \\
\hline Silt loam & $91.8 \%$ & & Shrub & 8 & Mankin et al., (2007) \\
\hline Loamy sand & & $63 \%$ & Forest/grass & 75 & Lowrance et al., (1984) \\
\hline
\end{tabular}


Table 2 Background information on the study sites

\begin{tabular}{|c|c|c|c|c|c|}
\hline Site No. & Site name & $\begin{array}{c}\text { Tree species before } \\
\text { harvesting }\end{array}$ & $\begin{array}{l}\text { Year of } \\
\text { planting }\end{array}$ & $\begin{array}{c}\text { Year of } \\
\text { harvesting }\end{array}$ & Main vegetation type \\
\hline 1 & Srahrevagh & lodgepole pine & 1971 & 2005 & $\begin{array}{c}\text { Calluna vulgaris, Molinia carulea, } \\
\text { Eriophorum angustifolium }\end{array}$ \\
\hline 2 & Glendahurk-1 & lodgepole pine & 1971 & 2006 & $\begin{array}{c}\text { Molinia caerulea, Calluna } \\
\text { vulgaris, Juncus bulbous }\end{array}$ \\
\hline 3 & Altahoney & lodgepole pine & 1971 & 2006 & Calluna vulgaris, Juncus effusus \\
\hline 4 & Maumaratta & lodgepole pine & 1971 & 2007 & Molinia caerulea \\
\hline 5 & Goulaun & lodgepole pine & 1971 & 2008 & $\begin{array}{c}\text { Calluna vulgaris, Juncus bulbous, } \\
\text { Sphagnum sp. }\end{array}$ \\
\hline 6 & Glendahurk-2 & lodgepole pine & 1971 & 2008 & $\begin{array}{c}\text { Molinia caerulea, Calluna } \\
\text { vulgaris, }\end{array}$ \\
\hline 7 & Teevaloughan & $\begin{array}{l}\text { lodgepole pine and } \\
\text { Sitka spruce }\end{array}$ & 1971 & 2009 & - \\
\hline 8 & Glennamong & lodgepole pine & 1971 & 2009 & - \\
\hline 9 & Tawnynahulty & lodgepole pine & 1971 & 2009 & - \\
\hline
\end{tabular}


Figure 1 Locations of the study sites (Site 1: Srahrevagh; site 2: Glendahurk-2; site 3:

Altahoney; site 4: Maumaratta; site 5: Goulaun; site 6: Glendahurk-1; site 7: Teevaloughan; site 8: Glennamong; site 9: Tawnynahulty).

Figure 2 Relationship between biomass and $\mathrm{P}$ content of the above ground vegetation and years after harvesting

Figure 3 Successful germination rates of ten grass species examined in laboratory conditions (Error bars indicate standard deviation)

Figure 4 Germination rates of ten grass species planted in the trial experimental

Figure 5 Biomass and $\mathrm{P}$ content of above ground vegetation in the study plots and control in the Glennamong (Plot 1: $100 \mathrm{~m}^{2}$, Plot 2: $360 \mathrm{~m}^{2}$, Plot 3: $660 \mathrm{~m}^{2}$; The bars indicate the standard deviation)

Figure 6 Water extractable phosphorus (WEP) in the study plots and control area in Glennamong (Plot 1: $100 \mathrm{~m}^{2}$, Plot 2: $360 \mathrm{~m}^{2}$, Plot 3: $660 \mathrm{~m}^{2}$; The bars indicate the standard deviation) 


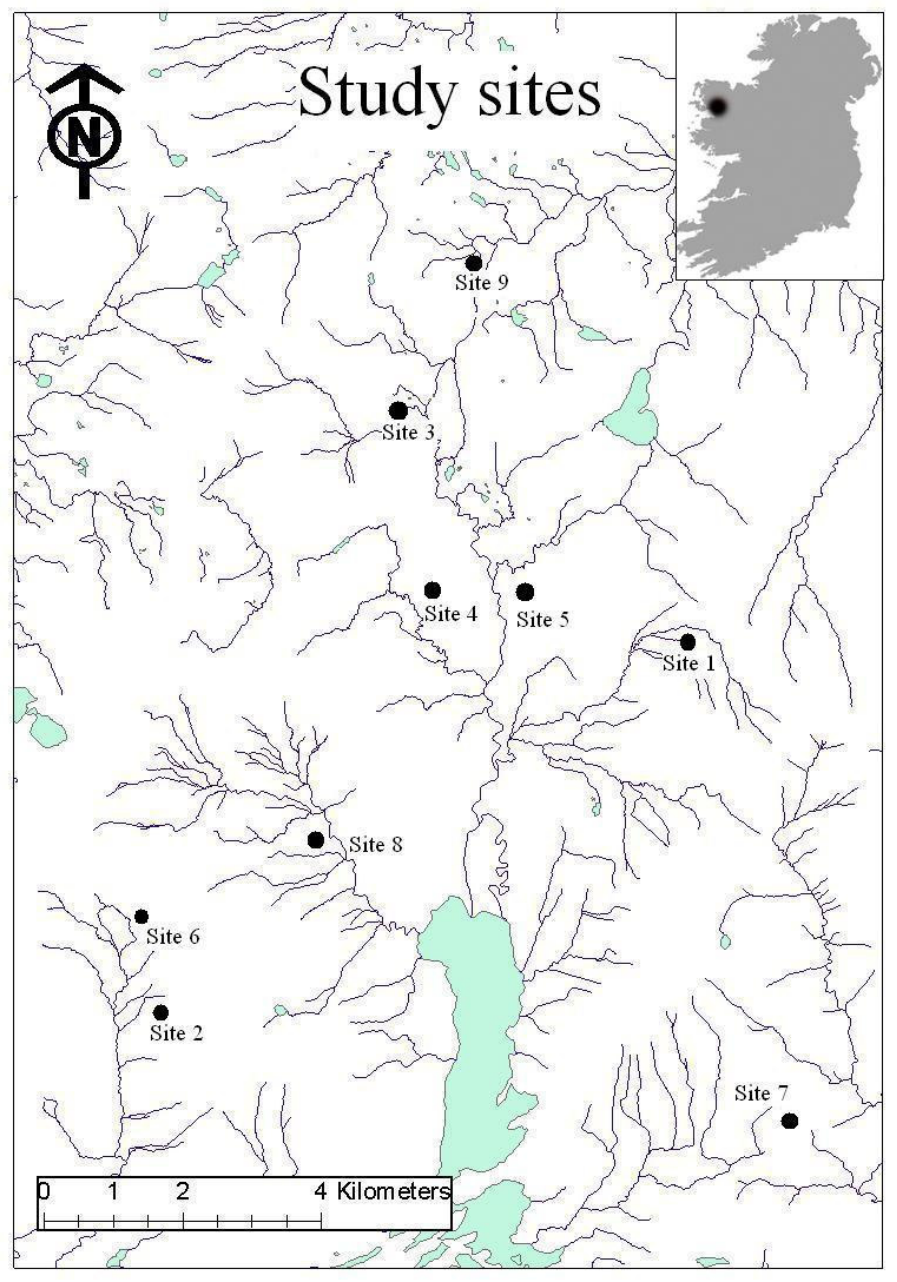

Figure 1 


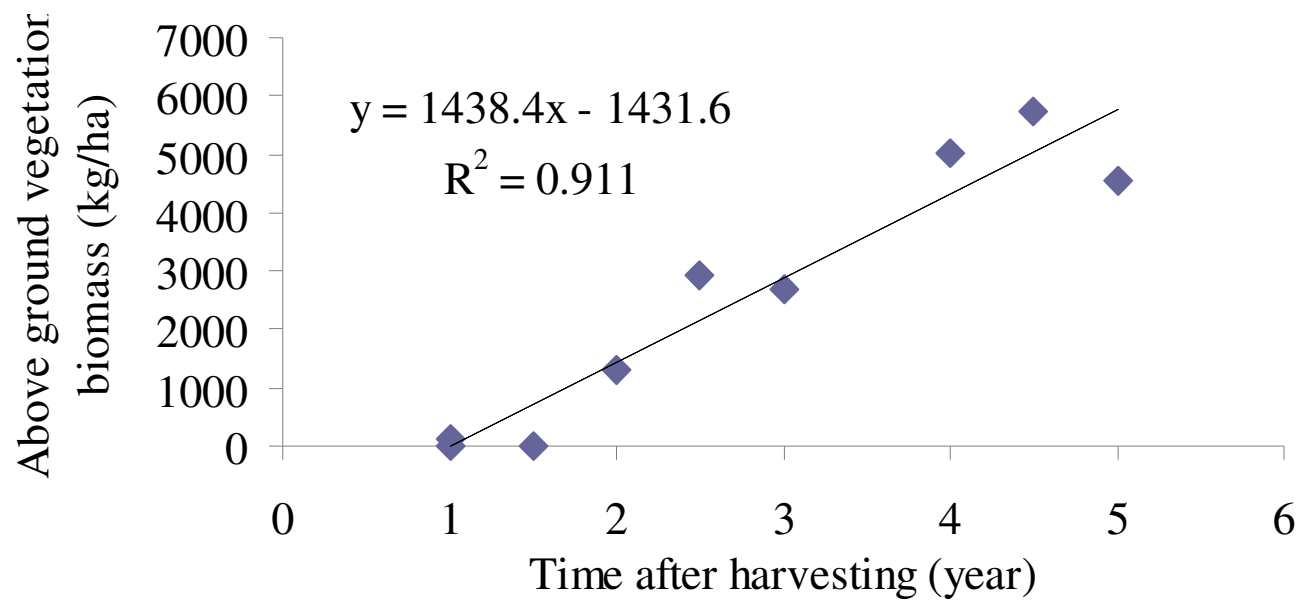

Figure 2a

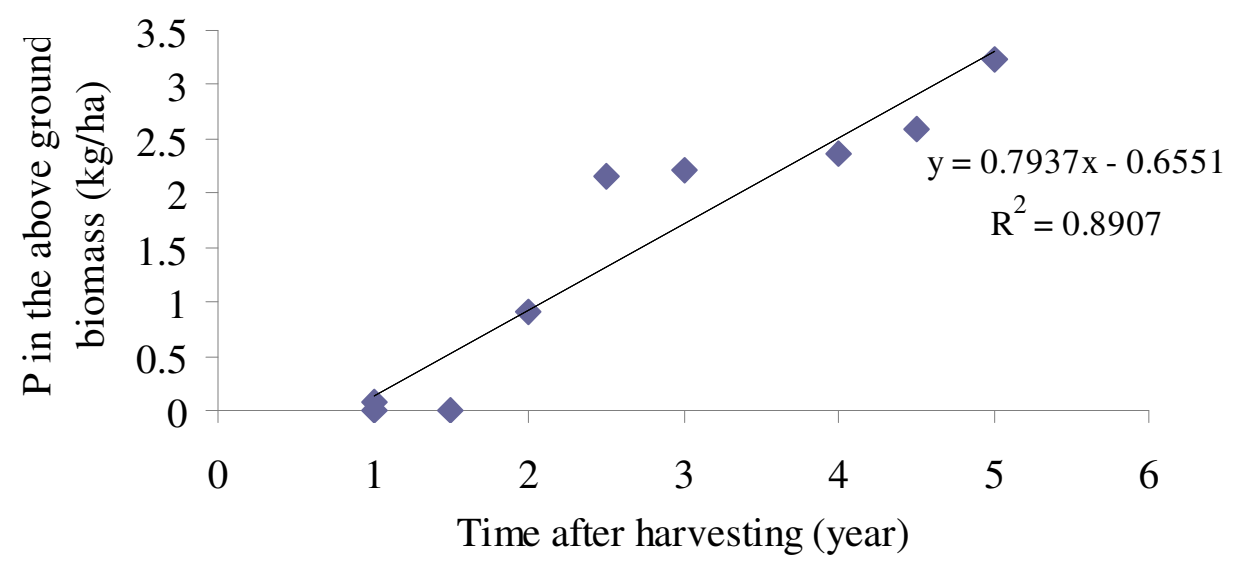

Figure $2 b$ 


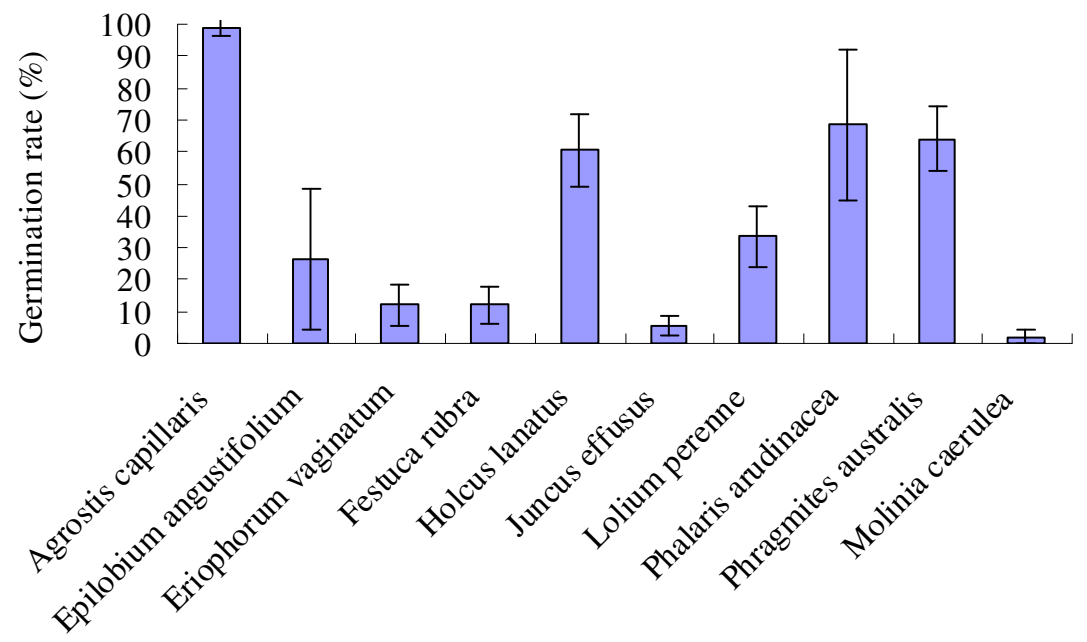

Figure 3 


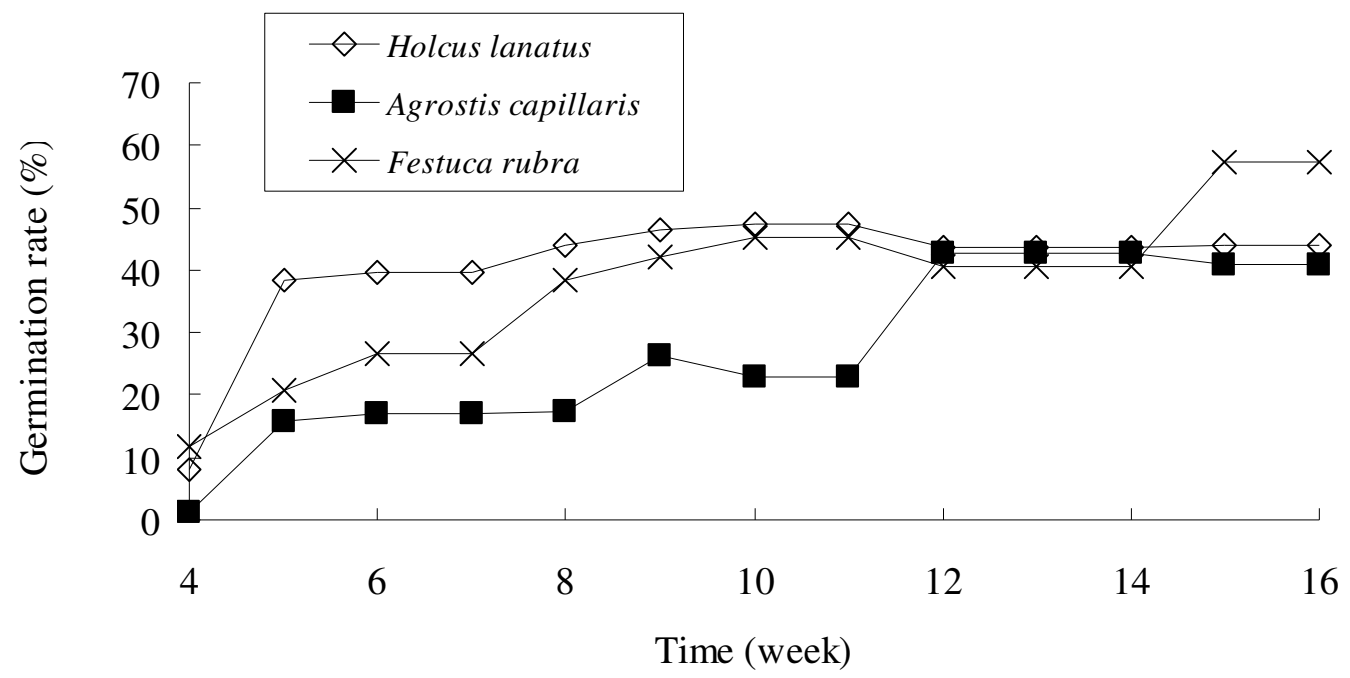

Figure 4a

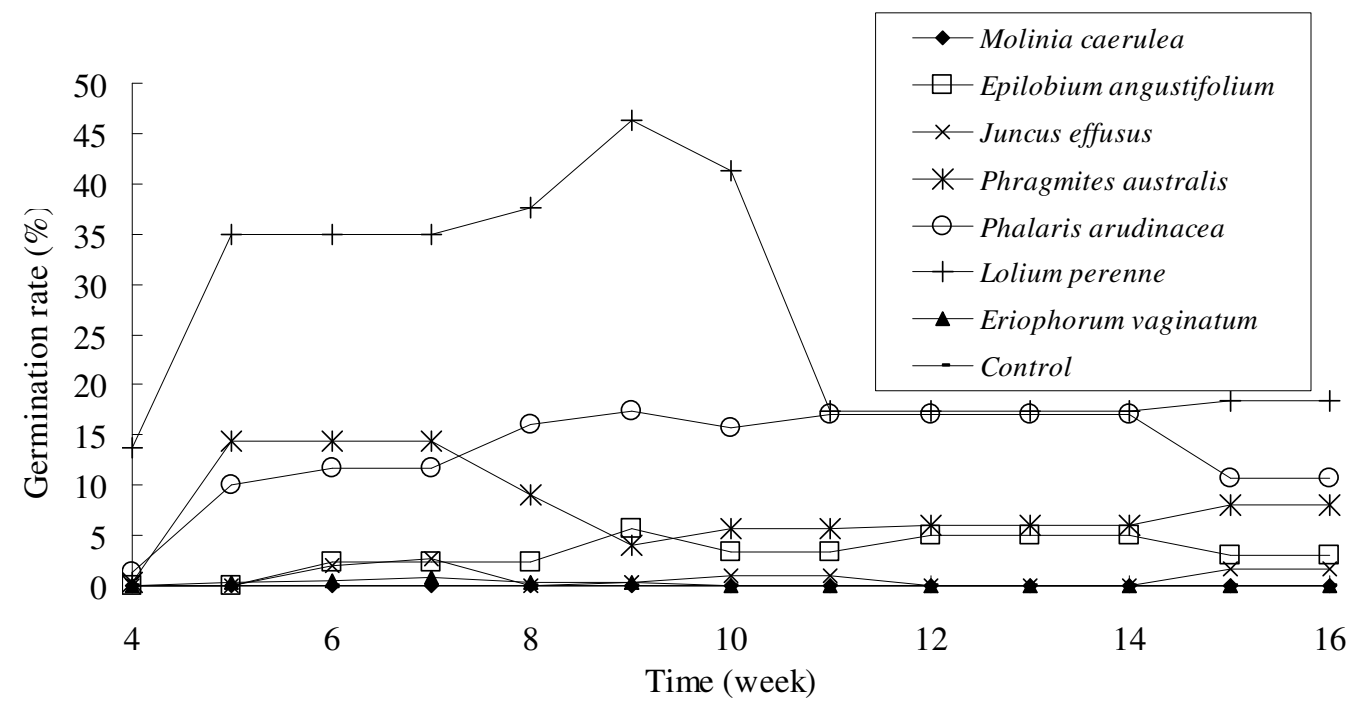

Figure $4 b$ 


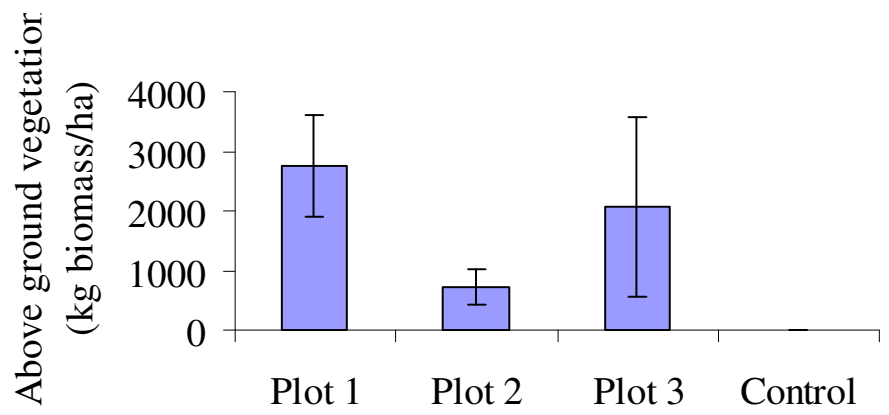

Figure 5a

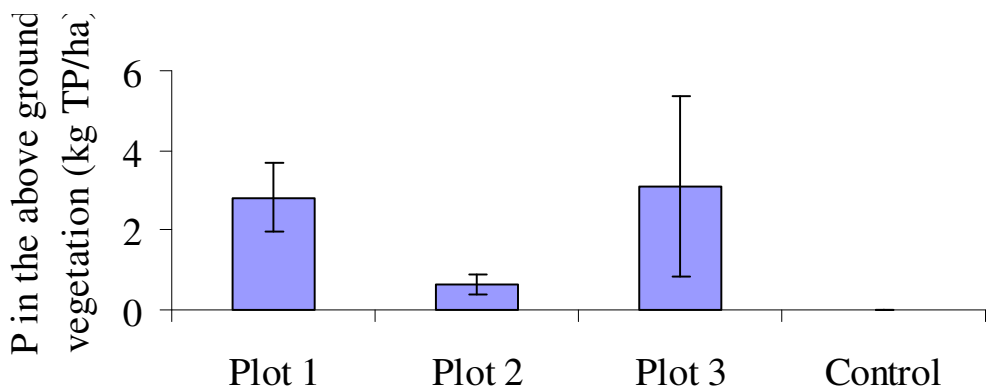

Figure $5 b$ 


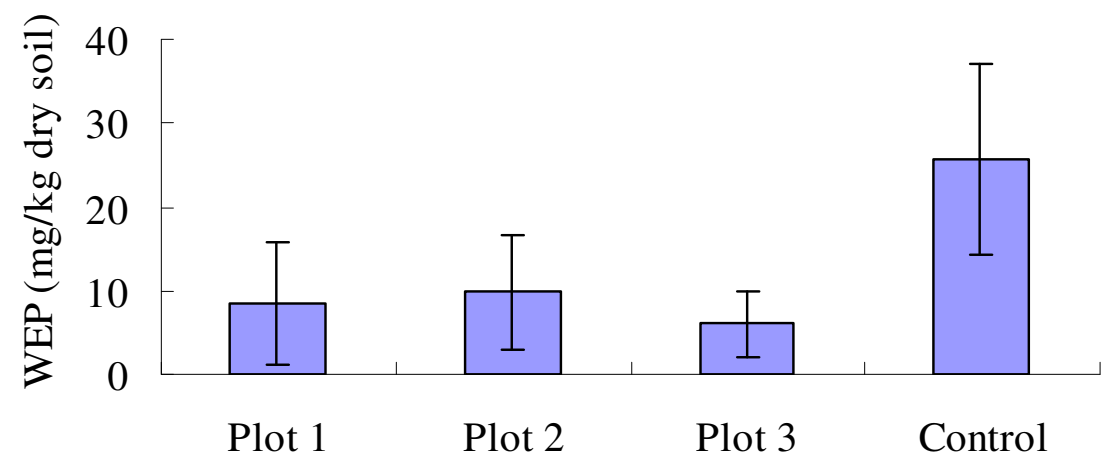

Figure 6 